\title{
Review of immunoglobulin G4-related salivary diseases and a case of Küttner's tumor
}

\section{Immünglobülin G4 ilişkili tükürük bezi hastalıklarnna bakışve bir Küttner tümörü olgusu}

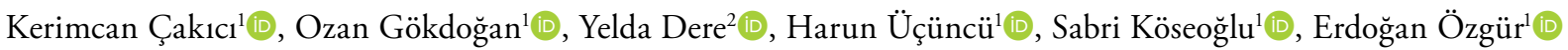

${ }^{1}$ Department of Otolaryngology, Muğla Sıtkı Koçman University Faculty of Medicine, Muğla, Turkey

${ }^{2}$ Department of Medical Pathology, Muğla Sıtkı Koçman University Faculty of Medicine, Muğla, Turkey

\begin{abstract}
Salivary glands can be affected by autoimmune diseases. Although Sjögren syndrome is the most common form of autoimmune salivary gland diseases, many other diseases may affect the salivary glands mainly through immunoglobulin G4 (IgG4)-related reactions. While Sjögren's syndrome affects the exocrine gland duct, IgG4-related disease usually affects the parenchyma of the salivary gland via an autoimmune reaction. A Küttners' tumor is a rare salivary gland disease related with IgG4+ lymphocytic infiltration and fibrosis. Herein, we report an adult male case of Küttner's tumor of the submandibular gland and discuss its clinical features, diagnostic methods, and treatment algorithms in the light of the literature data.
\end{abstract}

Keywords: Immunoglobulin G4-related disease, Küttner's tumor, sialadenitis.

Salivary gland diseases are primarily studied under two main headings: neoplastic and non-neoplastic diseases. Among the non-neoplastic salivary gland disorders, infections, sialolithiasis, and chronic sialadenitis can be listed. In chronic sialadenitis, one of the most important factors is autoimmune salivary gland involvement. Based on the histological structure of the main salivary glands, they consist of salivary gland parenchyma and salivary gland ductus. In autoimmune diseases, the body gives a reaction to its own tissues. Therefore, when the salivary glands are affected, parenchyma, ductus or both may become affected, as well.
$\ddot{O} Z$

Tükürük bezleri otoimmün hastalıklardan etkilenebilir. Sjögren sendromu otoimmün tükürük bezi hastalıklarının en yaygın türü olmasına karşın, başlıca immünoglobülin G4 (IgG4) ilişkili reaksiyonlar ile birçok başka hastalık da tükürük bezlerini etkileyebilmektedir. Sjögren sendromu ekzokrin bez kanalını tutarken, IgG4 ilişkili hastalıklar genellikle otoimmüm reaksiyonlar ile tükürük bezlerinin parankimlerini tutar. Küttner tümörü nadir görülen bir tükürük bezi hastalığı olup, patolojik IgG4+ lenfositik infiltrasyon ve fibrozis ile ilişkilidir. Bu yazıda, submandibüler bezde Küttner tümörü olan erişkin bir erkek olgu sunuldu ve literatür verileri ışığında hastalığın klinik özellikleri, tanı yöntemleri ve tedavi algoritmaları tartışıldı.

Anahtar sözcükler: Küttner tümörü, sialoadenit, IgG4 ilişkili hastalik.

The most important autoimmune disease which affects the salivary glands is Sjögren's syndrome. In this disease, all the secretory organs are affected and symptoms such as dry mouth and eye may develop. Other than Sjögren's syndrome, salivary glands can be involved due to the immunoglobulin G4 (IgG4)-related autoimmune process. In recent years, the term used for this condition has been IgG4-related sialadenitis. ${ }^{[1]}$ Indeed, IgG4-related autoimmune reaction can affect all organs of the body. The most frequently invaded organ due to IgG4 is the pancreas, followed by the head and neck area. In this case, the targeted tissues

Received: November 27, 2018 Accepted: July 11, 2019 Published online: September 03, 2019

Correspondence: Kerimcan Çakııı, MD. Muğla Sıtkı Koçman Üniversitesi Tıp Fakültesi Kulak Burun Boğaz Anabilim Dalı, 48000 Gülağzı, Muğla, Turkey. e-mail: kerim_cak@hotmail.com 
as different from Sjögren's syndrome are not the gland tissues, but the ligaments. Ligaments are infiltrated by $\mathrm{CD}^{+}, \mathrm{CD}^{+} \mathrm{T}$ lymphocytes together with $\mathrm{IgG} 4-$ positive plasma cells.

A Küttner's tumor, which is also known as submandibular sclerosing sialadenitis, is one of the diseases in the IgG4-related disease (IgG4-RD) spectrum. Diseases related to IgG4-RD involve a condition consisting of a series of disorders which share certain pathological, serologic, and clinical characteristics, which is defined in a clearer manner in terms of immunity. The main characteristics include swelling of the organs in a tumor-like manner, a rich lymphoplasmacytic infiltration, and the existence of variable fibrosis which has a characteristic vortex-like pattern. ${ }^{[1]}$ This disease is a rarely seen pathology which progresses with $\mathrm{IgG} 4^{+}$positive lymphocyte infiltration and fibrosis. The clinical symptoms and morphological appearance of the disease can be confused with malignancies invading the salivary glands, or Sjögren's syndrome, and other autoimmune diseases. In the definitive diagnosis of the disease, immunohistochemical methods are of utmost importance.

Herein, we report an adult male case of Küttner's tumor of the submandibular gland and discuss its clinical features, diagnostic methods, and treatment algorithms in the light of the literature data.

\section{CASE REPORT}

A 50-year-old male patient was admitted to the otorhinolaryngology outpatient clinic with complaints of a swelling under the right chin and having intermittent pain for the past one year. At the time of admission, he was free from symptoms. The possible relationship between swelling and food intake and the patient reported that symptoms such as swelling and pain sometimes occurred after meal. His medical history was non-specific without any comorbidities. In his detailed family history, there was no history of a malignancy or an autoimmune disease. On his physical examination, the right submandibular gland was about $2.5 \mathrm{~cm}$ in size and it was firm and movable. On palpation, there was no pain and sensitivity in the submandibular gland. An additional mass or lymphadenopathy was not found in the neck examination. On ultrasonographic examination, a diffuse growth was observed in the submandibular gland. A mass which took up a significant amount of area in the submandibular gland or sialolithiasis was not found. The patient was recommended diagnostic fine-needle aspiration biopsy due to the right-sided submandibular mass. However, the biopsy was not carried out and it was decided with the patient to carry out diagnostic submandibular gland excision. A written informed consent was obtained from the patient.

Right submandibular gland excision was performed under general anesthesia. During the operation, no pathologies other than the firmness in the submandibular gland were observed. Additional complications were not observed in the postoperative period. The pathology result was compatible with cross section of a greyyellow-colored tissue piece of $3.5 \times 2.5 \times 1.8 \mathrm{~cm}$ with diffuse, firm consistency, and lobular at certain regions on gross examination. On microscopic examination, a distinct lymphoplasmacytic infiltration which formed the distinct lymphoid follicle sporadically accompanied by variable parenchymal fibrosis (Figures 1-3) was observed. The findings were reported as compatible with chronic sclerosing sialoadenitis (Küttner's tumor). Since it was a IgG4-RD, a rheumatological evaluation was ordered. In the further analyses in the rheumatology

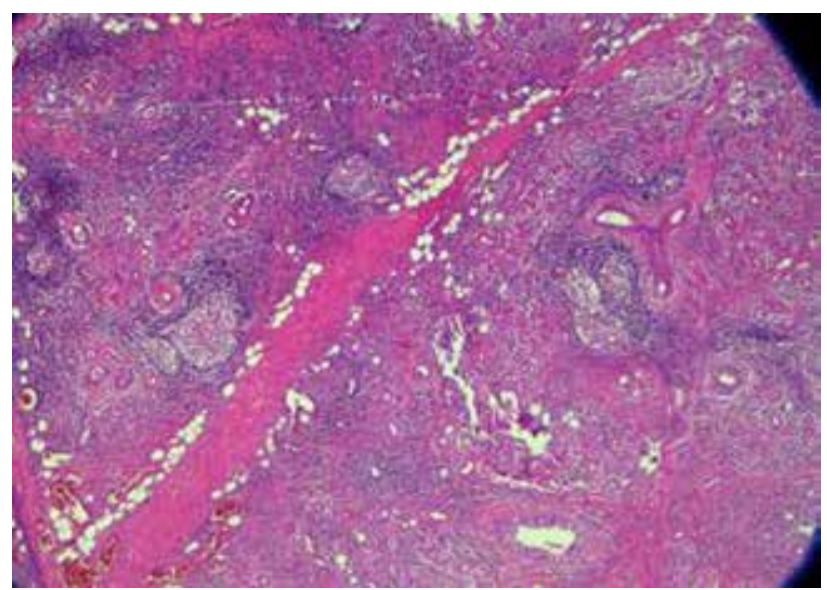

Figure 1. Lymphoplasmacytic inflammation forming lymphoid follicle structure, fibrosis $(\mathrm{H}-\mathrm{E} \times 100)$.

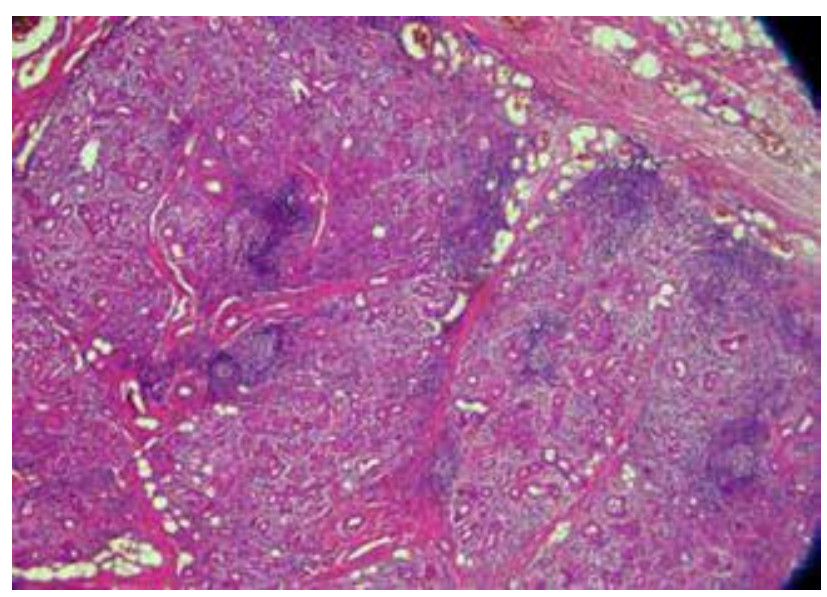

Figure 2. Irregular expansions in ductus $(\mathrm{H}-\mathrm{E} \times 100)$. 


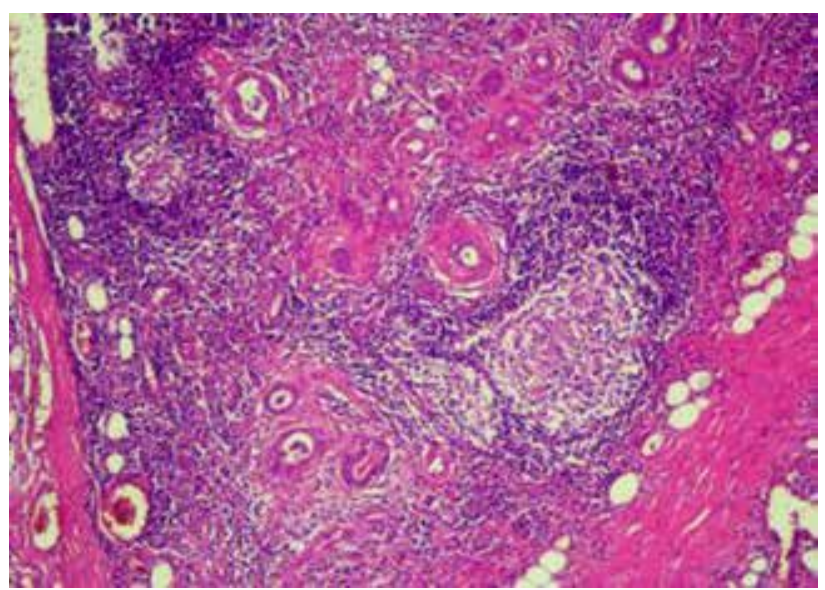

Figure 3. Dense periductal lymphoplasmacytic inflammation $(\mathrm{H}-\mathrm{E} \times 100)$.

clinic, serum IgG4 level was found to be normal. For systemic autoimmunity, no additional pathology was found.

\section{DISCUSSION}

A Küttner's tumor or submandibular sclerosing sialadenitis, is related to $\operatorname{IgG} 4$ which progresses with the fibro-inflammatory process. The IgG4-related involvement was first defined in 2001 by Hamano et al. ${ }^{[2]}$ who described a case of IgG4-related autoimmune pancreatitis. It can involve the whole body and head and neck area is the most frequently invaded area. Later on, a consensus report related to $\mathrm{IgG} 4$ was reported for the first time in $2011 .^{[3]}$ The major salivary glands, parotid and submandibular glands, can be frequently occupied by IgG4-RD. The differential diagnosis of the involvement from the Sjögren's syndrome and its sub-categories should be conducted with care. Currently, it has still not been shown how the IgG4-related reaction is initiated. In normal conditions, IgG4 proportionally constitutes an area less than $5 \%$ within the subclasses of $\mathrm{IgG}$. The main property of this molecule is that it consists amino acid variation in the central parts of two heavy chains and it can be separated easily. As a result of the separation, it joins the other half of the molecules randomly and asymmetrical bispecific antibodies are formed which have two different antigen binding fragments. Through this characteristic, it easily forms immune complexes and can be bound to $F_{c}$ receptors and complements with a low affinity. As a consequence, it can initiate an immune reaction, even if it is limited. ${ }^{[3]}$

In immune inflammation related to $\mathrm{IgG} 4$, the $\mathrm{T}$ helper 2 and $\mathrm{T}$ regulator cells play an important role. Instead of the Th1 and Th17 subtypes which play a critical role in classical autoimmune reactions, $\mathrm{T}$ helper 2 and $\mathrm{T}$ regulator are major components. ${ }^{[3,4]} \mathrm{In}$ general, IgG4-RDs are seen in middle-aged and elderly males. Parotid and/or submandibular glands can be frequently inhibited unilaterally or bilaterally. Although IgG4-RDs are mostly type 1 autoimmune pancreatitis, retroperitoneal fibrosis can occur with IgG4-dependent tubulointerstitial nephritis and the involvement of many other organs. Gender distinction also displays differences in the involvement of head and neck. In IgG4-dependent sialadenitis and $\mathrm{IgG} 4$-dependent ophthalmic diseases, the male and female rates are almost equal to each other. ${ }^{[1]}$ The presented case was also male. Clinically, there was firmness in the salivary glands. Sometimes, this can be confused with a malignancy. The disease is frequently related to microlithiasis. In the histological analysis, while the lobular structure of the salivary gland was preserved, there was a distinct lymphoplasmacytic inflammation, irregular lymphoid follicles which were not distinct from lymphoepithelial lesions and which had an expanded germinal center and acinar atrophy. The key morphological appearance of IgG-RDs is vortex-like pattern with dense lymphoplasmacytic infiltration, and frequently with obliterative phlebitis and eosinophilic infiltration which may vary from mild to severe. Interlobular fibrosis which develops as a result of active fibroblast and lymphoplasmacytic infiltration is the typical finding. In glandular organs, infiltration is more likely to be gathered around the ductal structures. ${ }^{[5]}$

Another cause of IgG4-related autoimmune sialadenitis is Mikulicz's disease which is characterized by the involvement of the lacrimal, parotid, and submandibular glands in an idiopathic, painfree, bilateral, symmetrical, and permanent pattern. Mikulicz's disease and primary Sjögren's syndrome share similar histological characteristics. In the histopathological analysis, severe mononuclear cell infiltration and lymphoid follicles around ductal and acinar cells are observed. Mikulicz's disease can be differentiated from Sjögren's syndrome by the IgG4 plasma cells around the ductal and acinar cells and lymphoid follicles. ${ }^{[6]}$ In the differential diagnosis of Küttner's tumors, other inflammatory processes such as IgG4-related autoimmune sialadenitis, marginal zone lymphoma (MALT), and Sjögren's syndrome and lymphoepithelial sialadenitis should be considered. The most benign and malign tumors of the submandibular gland successively are pleomorphic adenomas and adenoid cystic carcinomas. The differential diagnosis of these diseases should be also taken into consideration. ${ }^{[7]}$ Clinically, the rate of dry mouth in IgG4-related salivary gland involvement is about $30 \%$. In the presented case, dry mouth was not observed. The diseases presenting 
with IgG4-related salivary gland diseases, which account for 15 to $30 \%$, are pancreatitis, sclerosing cholangitis, and asthma. In addition, lacrimal gland involvement, sinonasal disorders, and cervical lymphadenopathy are the frequent findings. ${ }^{[1]}$ In the presented case, no involvement other than cervical lymphadenopathy was observed. The most commonly used screening method for salivary gland pathologies are ultrasonographic analyses. In Küttner's tumor, nodular pattern and microlithiasis together with ductus expansion are frequently observed. ${ }^{[5]}$ In the presented case, diffuse growth was seen in the submandibular gland. The fine-needle aspiration biopsy, which is often used in the differential diagnosis of salivary gland pathologies, did not work in this case.

In the analysis of surgical analysis, in IgG4-related salivary gland involvement, there are three basic histopathological findings: IgG4-positive plasma cell infiltration, dense fibrosis, and obliterative endarteritis. For definitive diagnosis, IgG4-positive cell/IgG-positive cell amount is analyzed. In the histochemical analysis of the biopsy material, the rate of $\mathrm{IgG} 4^{+} / \mathrm{IgG}^{+}$over $50 \%$ and observation of at least $30 \mathrm{IgG}^{+}$cells in each high growth is important for the diagnosis of IgG4-related salivary gland involvement. ${ }^{[8]}$ In our case, all histological findings were observed clearly and IgG4 was not able to be applied, since this antibody is not available in our institution. In such cases, an increase in blood immunoglobulin levels are observed. In patients with IgG4-related salivary gland involvement, a significant increase in serum $\operatorname{IgG}, \operatorname{IgG} 2, \operatorname{IgG} 4$, and $\operatorname{IgE}$ levels are observed. However, serum eosinophilic rate also increases and the complement level decreases. Serum IgG4 level may increase in certain cases, as well. In the presented case, serum $\operatorname{IgG} 4$ levels were found to be normal. A serum IgG4 level of over $>135 \mathrm{mg} / \mathrm{dL}$ is defined as the threshold value for the diagnosis. In addition, a linear relationship is observed between serum IgG4 levels and the inflammatory process in the salivary gland and, therefore, serum IgG4 level is an important determinant in terms of the effectiveness of the treatment and follow-up. ${ }^{[9,10]}$

While medical treatment is used in IgG4-related autoimmune reactions, there is a limited number of publications related to medical treatment in salivary gland involvement in the literature. The possible reason for this is that most diagnoses are based on pathological analyses. However, medical treatment used in autoimmune diseases can be used. In this respect, the reaction state to systemic steroids has been defined as a clinic entity in the differentiation between Mikulicz's disease and Sjögren's syndrome, until recently. In addition, IgG4-RDs can cause serious organ dysfunctions and, thus, when vital organs are involved, aggressive treatment is necessary. Glucocorticoids are the first-line medical therapy. Glucocorticoids are usually effective, although disease may flare when the treatment is discontinued. Azathioprine, mycophenolate mofetil, and methotrexate are used frequently after glucocorticoid-induced remission; however, their efficacy has never been investigated in clinical trials. ${ }^{[8]}$

To date, there is no study showing whether IgG4-RDs are predisposing for MALT or other lymphomas. Although, in a few reported cases, IgG4-RD was associated with lymphoma, further studies are still needed. In a study, it was reported that rather than IgG4-RD causing malignancy, malignancies may also cause IgG4-RD.

In conclusion, in the differential diagnosis of autoimmune head and neck pathologies, IgG4-RDs such as Mikulicz's disease, sclerosing sialadenitis (Küttner's tumor), inflammatory pseudotumor, chronic sclerosing dacryoadenitis, and Riedel's thyroiditis should be considered. Early diagnosis and treatment of these diseases can prevent serious organ dysfunctions and progressive fibrosis. In all patients diagnosed with IgG4-RDs, malignancies must be ruled out. A careful follow-up in a multidisciplinary manner is necessary, and other systemic diseases which may be associated with IgG4 should be excluded. Due to the systemic involvement characteristic of this disease, long-term follow-up is required.

\section{Declaration of conflicting interests}

The authors declared no conflicts of interest with respect to the authorship and/or publication of this article.

\section{Funding}

The authors received no financial support for the research and/or authorship of this article.

\section{REFERENCES}

1. Mulholland GB, Jeffery CC, Satija P, Côté DW. Immunoglobulin G4-related diseases in the head and neck: a systematic review. J Otolaryngol Head Neck Surg 2015;44:24

2. Hamano H, Kawa S, Horiuchi A, Unno H, Furuya N, Akamatsu $\mathrm{T}$, et al. High serum IgG4 concentrations in patients with sclerosing pancreatitis. $\mathrm{N}$ Engl J Med 2001;344:732-8.

3. Dijkstra PF. Classification and differential diagnosis of sialographic characteristics in Sjögren syndrome. Semin Arthritis Rheum 1980;10:10-7.

4. Deshpande V, Zen Y, Chan JK, Yi EE, Sato Y, Yoshino $\mathrm{T}$, et al. Consensus statement on the pathology of IgG4related disease. Mod Pathol 2012;25:1181-92. 
5. Zen Y, Nakanuma Y. IgG4-related disease: a cross-sectional study of 114 cases. Am J Surg Pathol 2010;34:1812-9.

6. Yamamoto M, Takahashi H, Ohara M, Suzuki C, Naishiro $\mathrm{Y}$, Yamamoto $\mathrm{H}$, et al. A new conceptualization for Mikulicz's disease as an IgG4-related plasmacytic disease. Mod Rheumatol 2006;16:335-40.

7. Wallace ZS, Wallace CJ, Lu N, Choi HK, Stone JH. Association of IgG4-Related Disease With History of Malignancy. Arthritis Rheumatol 2016;68:2283-9.

8. Stone JH, Zen Y, Deshpande V. IgG4-related disease.
N Engl J Med 2012;366:539-51.

9. Moriyama M, Tanaka A, Maehara T, Furukawa S, Nakashima H, Nakamura $S$. $T$ helper subsets in Sjögren's syndrome and IgG4-related dacryoadenitis and sialoadenitis: a critical review. J Autoimmun 2014;51:81-8.

10. Ihrler S, Baretton GB, Menauer F, Blasenbreu-Vogt S, Löhrs U. Sjögren's syndrome and MALT lymphomas of salivary glands: a DNA-cytometric and interphasecytogenetic study. Mod Pathol 2000;13:4-12. 